\title{
STRATEGI LEMBAGA AMIL ZAKAT INFAQ SHADAQAH MUHAMMADIYAH (LAZISMU) DALAM PEMBERDAYAAN PEREKONOMIAN MUSTAHIK DI BANYUMAS TAHUN 2010-2014
}

\author{
Azqiyatul Mu'takhiroh ${ }^{1}$, Ida Nurlaeli ${ }^{2}$ \\ 1Universitas Muhammadiyah Purwokerto, Email : azqidholip@gmail.com \\ 2UIN Walisongo Semarang, Email : idanurlaeli_1326@yahoo.com
}

\begin{abstract}
ABSTRAK
Penelitian ini bertujuan untuk mengetahui bagaimana strategi lembaga amil zakat infaq shadaqah dalam mengatasi pemberdayaan perekonomian mustahik di Banyumas. Jenis penelitian ini menggunakan metode deskriptif kualitatif yang penulis laksanakan dengan menggunakan data kualitatif. Dalam pengumpulan data mennggunakan observasi, wawancara dan dokumentasi. Setelah data terkumpul kemudian dianalisis dengan menggunakan tiga langkah yaitu reduksi data, penyajian data, dan penarikan kesimpulan. Hasil penelitian ini adalah (1) zakat sangat berperan dalam pemberdayaan perekonomian mustahik hal ini terbukti dengan berkembangnya usaha dari para mustahik yang semakin meningkat, (2) penghimpunan dana zakat, infaq, shaqdaqah (ZIS) diperoleh dengan cara jemput zakat atau dengan cara muzakki menyerahkan dana kepada Lembaga Amil Zakat Infaq Shadaqah Muhammadiyah (LAZISMU), (3) berkembangnya usaha yang dilakukan oleh mustahik dapat menajdi tolak ukur seberapa besar strategi yang dilakukan LAZISMU dalam pemberdayaan perekonomian mustahik, (4) pengelolan dan pendistribusian dana zakat, infaq, shadaqah (ZIS) diprioritaskan pada program pendayagunaan yang produktif, (5) adanya faktor penunjang yaitu mempunyai sumber daya manusia yang baik dan manajemen pengelolaan yang kreatif, (6) adanya faktor penghambat yaitu masih banyaknya dari para pengurus Muhammadiyah yang belum memiliki kesadaran untuk membayar zakat, infaq, shadaqah (ZIS), minimnya respon dari para AUM untuk dapat bersinergi dengan LAZISMU untuk bekerjasama.
\end{abstract}

Kata-kata kunci : Strategi, Pemberdayaan, Perekonomian Mustahik.

\section{ABSTRACT}

This study aims to find out how the strategy of the amil zakat infaq shadaqah institution in overcoming the economic empowerment of mustahik in Banyumas. This type of research uses a qualitative descriptive method that the author carried out using qualitative data. In collecting data using observation, interviews and documentation. After the collected data is then analyzed using three steps, namely data reduction, data presentation, and conclusion. The results of this study are (1) zakat is very instrumental in economic empowerment mustahik this is evidenced by the development 
of the business of increasing mustahik, (2) the collection of zakat funds, infaq, shaqdaqah (ZIS) obtained by picking up zakat or by giving muzakki funds to the Amil Zakat Infaq Shadaqah Muhammadiyah Institution (LAZISMU), (3) the efforts made by Mustahik can be a measure of how much strategy LAZISMU has in empowering mustahik economics, (4) management and distribution of zakat, infaq, shadaqah funds (ZIS ) prioritized on productive utilization programs, (5) the existence of supporting factors, namely having good human resources and creative management management, (6) the existence of inhibiting factors, there are still many Muhammadiyah administrators who do not have the awareness to pay zakat, infaq, shadaqah (ZIS), the lack of response from the AUM to be able to work together with bro LAZISMU to cooperate.

Keywords : Strategy, Empowerment, Economy Mustahik.

\section{PENDAHULUAN}

Zakat merupakan ibadah yang tidak hanya berhubungan dengan nilai ketuhanan saja namun berkaitan juga dengan hubungan kemanusiaan yang bernilai sosial/maliyahijtimah'iyyah (Hafidhudin,2002:1). Zakat memiliki manfaat yang sangat penting dan strategis dilihat dari sudut pandang ajaran Islam maupun dari aspek pembangunan kesejahteraan umat. Hal ini telah dibuktikan dalam sejarah perkembangan Islam yang diawali sejak masa kepemimpinan Rasulullah SAW. Zakat telah menjadi sumber pendapatan keuangan negara yang memiliki peranan sangat penting, antara lain sebagai sarana pengembangan agama Islam, pengembangan dunia pendidikan dan ilmu pengetahuan, pengembangan infrastruktur, dan penyediaan layanan bantuan untuk kepentingan kesejahteraan sosial masyarakat yang kurang mampu

Peranan zakat sesuai dengan kondisi ekonomi masyarakat miskin di Indonesia yang masih membutuhkan berbagai macam layanan bantuan, namun masih kesulitan dalam memperoleh layanan bantuan tersebut guna meningkatkan kesejahteraan masyarakatnya. Dilihat dari fenomena itulah, Indonesia yang mayoritas penduduknya beragama Islam sebenarnya memiliki potensi yang strategis dan sangat layak untuk dikembangkan dalam menggerakkan perekonomian negara. Melalui penggunaan salah satu instrumen pemerataan pendapatan. Selain sebagai ibadah dan kewajiban juga telah mengakar kuat sebagai tradisi dalam kehidupan masyarakat Islam. Oleh karena itu, zakat, infaq, dan shadaqah yang telah menjadi bagian dari kehidupan masyarakat Islam di Indonesia, didukung dengan besarnya kekayaan sumber daya alam yang dimiliki 
bangsa Indonesia, sehingga Indonesia adalah negara yang memiliki potensi zakat yang cukup besar.

Zakat juga merupakan salah satu instrumen dalam mengentaskan kemiskinan karena dana yang bisa dikumpulkan seperti infaq, shadaqah, wakaf, wasiat, hibah serta sejenisnya. Oleh sebab itu, adanya dukungan stakeholders dalam memperbesar pengumpulan dananya, namun pula mampu meningkatkan skala program, gerakan, dan kesadaran (Makhrus, 2014: 26). Sumber dana-dana tersebut merupakan pranata keagamaan yang memiliki kaitan secara fungsional dengan upaya pemecahan masalah kemiskinan dan kepincangan sosial. Dana yang terkumpul merupakan potensi besar yang dapat didayagunakan bagi upaya penyelamatan nasib puluhan juta rakyat miskin di Indonesia yang kurang dilindungi oleh sistem jaminan sosial yang terprogram dengan baik dana zakat yang dikelola dengan sistem dan manajemen yang amanah, profesional dan integral dengan bimbingan dan pengawasan dari pemerintah dan masyarakat akan menjadi pemacu gerak ekonomi di dalam masyarakat dan meyehatkan tatanan sosial sehingga makin bekurangnya kesenjangan antara kelompok masyarakat yang mampu dan kelompok masyarakat yang kurang mampu (Khasanah, 2010: 39).

Banyak kemajuan yang telah dicapai dengan dana zakat tersebut, seperti pembangunan masjid, mushala, pesantren, gedung universitas, dan rumah sakit. Hanya, hal tersebut masih sangat kecil apabila dibandingkan dengan potensi yang demikian besar (Arif, 2012 : 394). Diperlukan strategi untuk dapat menggali potensi yang sangat besar tersebut. Dengan jumlah penduduk Indonesia yang sekitar 220 juta jiwa, dan hampir 80\% penduduknya beragama Islam, jika menggunakan perhitungan dengan pendekatan berdasarkan Produk Domestik Bruto (PDB) Indonesia, yaitu hanya dengan mengambil $2,5 \%$ dari PDB yang didapat, potensi penerimaan zakat di Indonesia bisa mencapai angka triliunan rupiah per tahun dan belum tergali secara maksimal. Hal ini disebabkan kurangnya kesadaran masyarakat untuk berzakat atau kurang kreatifnya pengelola zakat dalam pembuatan program pemberdayaan masyarakat. Faktor kepercayaan yang masih sangat penting bagi para pengelola zakat dalam kegiatannya menghimpun dana zakat yang ada (Arif, 2012 : 398) 
Lembaga amil zakat infaq shadaqah Muhammadiyah (LAZISMU) sebagai salah satu lembaga filantropi Islam yang melakukan pemberdayaan masyarakat telah mempunyai program jangka panjang salah satunya pemberdayaan ekonomi masyarakat, yaitu untuk memberdayakan perekonomian mustahik masyarakat di Banyumas berdasarkan data jumlah mustahik yang ada di Lembaga amil zakat infaq shadaqah Muhammadiyah (LAZISMU) Banyumas kurang lebih 2.000 mustahik, pengumpulan Zakat hendaknya atau seharusnya merupakan sesuatu yang terprogram dan terencana, termasuk ditentukan jadwalnya dengan jelas, dan tetap berlandasan untuk beribadah kepada Allah dengan ikhlas. Dalam penanganan zakat ini, perlu dicamkan bahwa para pembayar Zakat hendaknya mengetahui kemana harta zakatnya itu dibagikan dan dimanfaatkan. Badan Amil Zakat harus mempunyai dokumen dan data atau pembukuan yang rici mengenai jumlah uang Zakat yang diterima, orang yang membayarnya, kemana digunakan, dan semacamnya. Sehingga sewaktu-waktu salah satu pembayar Zakat ingin tahu data rinci mengenai zakatnya, Badan Amil Zakat bisa memberi jawaban dengan memuaskan.

Lembaga zakat akan mencapai keberhasilan, yang bergantung pada komponen-komponen strategi pelaksanaan kegiatan, seperti berkaitan dengan pengelolaan, muzaki, mustahik, tenaga pelaksana, dan sarana prasarana. Komponen-komponen strategi tersebut adalah satu-kesatuan yang saling mendukung dalam pencapaian tujuan lembaga amil zakat. Bahwasanya, komponen satu dan yang lainnya saling melengkapi, sehingga komponen-komponen pelaksana kegiatan tersebut memberikan kontribusi yang sangat tinggi terhadap pencapaian tujuan lembaga amil zakat tersebut. Begitu juga halnya dengan strategi mustahik (penerima zakat), keberadaanya sangat dibutuhkan, terlebih pelaksanaan kegiatan zakat di sebuah daerah, penerima zakat merupakan subyek sekaligus obyek. Oleh karena itu, keberadaan penerima zakat bukan hanya sekedar suatu kebutuhan semata, akan tetapi lebih dari itu, penerima zakat harus bermutu (berkualitas) dalam meningkatkan kualitas hidup sehingga dapat menjadi muzaki. Artinya, harus ada strategi penerima zakat yang berkualitas. Sehingga penerima zakat dapat tumbuh dan berkembang sesuai dengan potensi fisik, kecerdasan intelektual, sosial, emosional, dan kejiwaan (psikologi) penerima zakat. 


\section{METODE PENELITIAN}

Jenis penelitian ini menggunakan jenis penelitian kualitatif. Penelitian ini dilaksanakan di Lembaga Amil Zakat Infaq Shadaqah Muhammadiyah (LAZISMU) banyumas periode Tahun 2010-2014 ataupun tergantung pada data yang diperlukan, interes dan tujuan penelitian (Sugiyono,2009:24). Teknik pengumpulan data dalam penelitian ini adalah wawancara, observasi, dan dokumentasi. Analisis data adalah salah satu upaya mencari dan menata secara sistematis catatan hasil observasi, wawancara, dan lain sebagainya untuk meningkatkan pemahaman peneliti tentang masalah yang diteliti dan menyajikannya sebagai temuan bagi orang lain (Muhadjir, 2002 : 142).

\section{HASIL DAN PEMBAHASAN}

Zakat (Bahasa Arab: زكاة; transliterasi: Zakah) adalah jumlah harta tertentu yang wajib dikeluarkan oleh orang yang beragama Islam dan diberikan kepada golongan yang berhak menerimanya (fakir miskin dan sebagainya) menurut ketentuan yang telah ditetapkan oleh syarak. Zakat merupakan rukun ketiga dari Rukun Islam. Zakat dari segi prakteknya adalah kegiatan bagi-bagi yang diwajibkan bagi umat Islam (Qardhawi, 1986 : 34). Islam, kebutuhan memang menjadi alasan untuk mencapai yang minimun, namun demikian kecukupan dalam standar hidup yang baik adalah hal yang paling mendasari dalam distribusi kekayaan, setelah itu baru dikaitkan dengan kerja dan kepemilikan pribadi. Makannya zakat sebagai slah satu instrumen disyariatkan dengan kalimat imperative (kata perintah), dengan begitu tanpa perlu lagi mecari alsan ekonomi, sistem zakat dapat diupayakan sebagai insrumen redistribusi income. Membayar zakat adalah kewajiban yang sangat penting bagi muslim, bahkan agama Islam sangat menganjurkan kepada umat muslim untuk menjadi dermawan dalam membelanjakan setiap kekayaannya, namun demikian, dalam menjalankan kewajiban zakat, umat muslim tetap harus hati-hati dan bisa memastikan bahwa aset dan pendapatan yang dihitung tidak berlebihan atau kewajiban dan pengeluarannya tidak dikurangi.

Lembaga amil zakat infaq shadaqah Muhammadiyah (LAZISMU) Banyumas adalah lembaga nirlaba tingkat Kabupaten yang berkhidmat dalam pemberdayaan masyarakat melalui pendayagunaan secara produktif 
dana zakat, infaq, wakaf dan dana kedermawanan lainnya baik dari perseorangan, lembaga, perusahaan dan instansi lainnya. Lembaga amil zakat infaq shadaqah Muhammadiyah (LAZISMU) Banyumas berdiri sejak 2 Oktober 2010 yang ditandai dengan Launching pembentukan dan pengukuhan pengurus oleh Ketua Pimpinan Daerah Muhammadiyah Banyumas. Lembaga ini merupakan jejaring lembaga amil zakat infaq shadaqah Muhammadiyah (LAZISMU) Lembaga Zakat Nasional yang di dirikan oleh Pimpinan Pusat Muhammadiyah sejak tahun 2002.

Latar belakang berdirinya lembaga amil zakat infaq shadaqah Muhammadiyah (LAZISMU) Banyumas; Pertama, adalah berangkat dari rasa keprihatinan Muhammadiyah atas persoalan kemiskinan dan kebodohan yang terus menyelimuti sebagian besar masyarakat dan upaya pembangunan manusia yang masih sangat rendah. Kedua, dengan zakat diyakini mampu memberikan sumbangsih dalam mendorong keadilan sosial, pembangunan manusia dan mengentaskan kemiskinan. Sebagai daerah yang terus berkembang secara perekomian Kabupaten Banyumas memiliki potensi zakat, infaq dan shadaqah yang terbilang cukup tinggi. Namun, potensi yang ada belum dapat dikelola dan didayagunakan secara maksimal sehingga tidak memberi dampak yang signifikan bagi penyelesaian persoalan yang ada.

Dalam operasional programnya, (LAZISMU) Banyumas didukung oleh Jaringan Multi Lini, sebuah jaringan konsolidasi JPS LAZISMU (Jejaring Penghimpun dan Salur lembaga amil zakat infaq shadqah Muhammdiyah (LAZISMU ) yang tersebar di hampir seluruh Kecamatan dan Desa di Kabupaten Banyumas. Dengan adanya JPS LAZISMU diharapkan dapat membuat pendayagunaan LAZISMU mampu menjangkau wilayah pelosok di Kabupaten Banyumas secara terfokus dan tepat sasaran. LAZISMU dalam pemberdayaan masyarakat di antaranya sebagai berikut : pertama, meningkatkan taraf perekonomian keluarga. Kedua, menambah penghasilan keluarga. Ketiga, menjadikan hidup keluarga saya makmur. Keempat, untuk membiaya anak sekolah. Kelima, modal usaha. Program LAZISMU Banyumas dan Kebijakan strategis tahun 2010-2012 dan tahun 2014 menujukkan bahwa proram tersebut sejalan dengan grand program yang diluncurkan oleh LAZISMU Nasional. 
Kebijakan ini selanjutnya dijabarkan kedalam berbagai program pendayagunaan yang fokus pada sasaran yang disusun berdasarkan analisa kebutuhan sasaran, berorientasi pada skala prioritas dan bertumpu pada spirit kreatifitas dan inovasi serta asas partisipatif dengan tetap memegang teguh prinsip-prinsip Syariah. Hasil akhir dari kebijakan program LAZISMU bertujuan untuk membangun kualitas sumber daya dan kemadirian masyarakat dan sistem sosial yang berkeadilan.

1. Pemberdayaan ekonomi kecil.

Pemberdayaan ekonomi kecil ini bertujuan membangun mental kewirausahaan dan kemandirian ekonomi masyarakat agar dengan kemampuannya sendiri dapat terlepas dari jerat kemiskinan dan mampu meningkatkan kualitas hidup menjadi lebih baik. Program ini meliputi :

a. Kewirausahaan pemuda. Dengan motto "Yang Muda Yang Berdaya", Program ini bertujuan untuk membangun etos kewirausahaan generasi muda dalam tiga ranah strategis. Program ini didesain dalam beberapa aktifitas program diantaranya: pendidikan dan pelatihan, pemagangan, beastudi kewirausahaan, pendampingan dan fasilitasi pendirian usaha serta bantuan permodalan usaha. Kebijakan strategis program ini adalah mengembangkan kewirausahaan generasi muda dalam konteks industry kreatif. Dimana peserta program akan didorong dan dididik untuk mampu mendirikan dan mengembangkan usaha berbasis kreatifitas.

b. Kampoeng kreatif. Adalah program pemberdayaan masyarakat desa melalui pengembangan industry kreatif (kerajinan, garmen, kesenian, dst) berbasis sumberdaya lokal. Program ini merupakan bagian dari upaya mewujudkan Gerakan Nasional Indonesia Kreatif. Aktifitas program Kampoeng Kreatif terdiri atas pembentukan kelompok-kelompok industri melalui strategi pemberdayaan kader pelopor. Posisi LAZISMU dalam program ini adalah sebagai lembaga intermediasi yang berperan dalam proses community development, pelatihan, permodalan dan akses permodalan, linkage sumberdaya dan fasilitasi pemasaran. 
Pemberdayaan ini sudah di lakukan di desa Karang Lewas dengan mengadakan kursus menjahit, komputer, montir, dan lainnya.

2. Pemberdayaan pertanian dan peternakan

Pmberdayaan pertanian dan peternakan memiliki aksi: tani mandiri yaitu program dengan pemberdayaan model one stop empowerment yang terdiri atas community development, pendampingan pengelolaan pertanian dan permodalan. Sementara program pemberdayaan masyarakat LAZISMU Banyumas tahun 2014 adalah, pertam, Rumah Kreatif Muhammadiyah (Kursus Gratis Life Skill), Indonesia Siaga, dan Toko Komunitas.

Operasional bidang pemberdayaan ekonomi masyarakat merupakan kebijakan strategis LAZISMU Banyumas yang menjadi unggulan yang mampu mengangkat warga masyarakat dari keterpurukan sektor ekonomi (kemiskinan) sekaligus kebodohan yang merupakan musuh umat Islam. Yakni dengan cara memberikan modal usaha kepada para mustahik yang ada di wilayah Purwokerto dan sekitarnya yaitu dengan dana yang variatif tergantung dengan jenis usaha yang akan dijalani yaitu berkisar antara $\mathrm{Rp}$ 500.00; - Rp 1.000.000; meskipun bantuan yang dari lazis tidak terlalu besar tapi diharapkan memberikan konstribusi riil untuk membantu mereka dalam menjalankan usahanya agar bisa membantu perekonomian keluarga. Berdasarkan arahan dan petunjuk peraktis dari badan pengurus maka badan pelaksana mendistribusikannya kepada para mustahik dengan skala prioritas dan tetap berdasarkan syari'at Islam.

Guna mengetahui strategi LAZISMU dalam pemberdayaan perekonomian mustahik di Kabupaten Banyumas yang dilakukan analisa dan wawancara pada masyarakat. Kemudian, dalam pengelolaan dan pendistribusian ada badan pelaksana ini merupakan badan yang bekerja dilapangan yang langsung berhubungan dan berhadapan dengan para muzaki dan mustahik. diawali dari penerimaan zakat infaq shadaqah dari para muzaki yaitu dengan cara jemput zakat atau para muzaki yang menyerahkan sebagian dari zakat infaq shadaqah kepada LAZISMU. Badan pelaksana lembaga amil zakat infaq shadaqah Muhammadiyah (LAZISMU) ini masing-masing menjalankan tugasnya dengan baik dan benar dengan setiap pendistribusian zakat dimusyawarahkan terlebih 
dahulu dengan para badan pengurus dan konsultan.

Sementara dengan adanya program pemberdayaan masyarakat yaitu bertujuan untuk membangun kualitas sumber daya manusia dan kemandirian masyarakat yaitu masyarakat yang betul-betul membutuhkan bantuan untuk mengangkat kondisi perekonomian mereka serta menciptakan sistem sosial yang berkeadilan sehingga tidak ada lagi jurang pemisah antara muzaki dan mustahik dan akan tercipta masyarakat yang adil dan makmur secara keseluruhan. LAZISMU juga tidak hanya membuat program pemberdayaan masyarakat saja melainkan masih ada banyak program yang dilaksanakan oleh LAZISMU sebagai salah satu lembaga nirbala yang berkhidmat dalam pemberdayaan masyarakat. Pengelolaan dana lembaga amil zakat infaq shadaqah Muhmmadiyah (LAZISMU) Banyumas berjalan dengan baik dan lancar dengan indikasi keberhasilannya dengan adanya :

1. Wali amanah (memberikan pertimbangan tertentu dalam pelaksanaan program kerja yang dijalankan oleh LAZISMU Banyumas, dewan syari'ah (bertugas memeberikan fatwa dan masukan untuk suksesnya kinerja Badan Pelaksana), badan pengawas (badan yang mengawasi setiap kinerja yang berada dilapangan secara langsung), badan pengurus (yaitu badan yang mengurusi setiap pemasukan dan pengeluaran yang ada di LAZISMU Banyumas dan badan pelaksana yaitu badan yang bertanggungjawab penuh dan melaporkan dengan pengurus dengan melaporkan seluruh program yang sudah dilaksanakan ataupun yang belim dilaksanakan). yang melaksanakan tugas sesuai dengan kewenangannya dengan baik, sehingga pengelolaan dan pendistiribusian LAZISMU terhadap masryakat yang kurang mampu dapat dijalankan sesuai yang telah direncanakan dan ditetapkan.

2. Muzakki yang telah mempercayakan zakat, infaq, dan shadaqahnya pada LAZISMU harus tetap istiqomah mengeluarkan sebagian zakat, infaq, shadaqah ( ZIS) selama 2 tahun sekali.

3. Mustahik juga harus mampu memperdayakan sebagain dari dana yang telah diberikan oleh LAZISMU harus dipergunakan dengan cara yang baik dan benar dan juga dapat digunakan dalam hal-hal produktif 
tidak sekedar komsumtif secara terperinci.

LAZISMU Banyumas mempunyai komitmen untuk meringankan beban masyarakat yang kurang mampu dan berpartisipasi untuk meringankan beban masyarakat banyumas dan sekitarnya karena daerah kabupaten banyumas sendiri memiliki potensi zakat yang cukup tinggi tetapi potensi yang sudah ada belum dapat dikelola dan didayagunakan dengan baik dan belum maksimal sehingga belum memberikan dampak yang signifikan bagi penyelesaian persoalan yang ada. Jadi strategi yang dilakukan oleh LAZISMU sudah djalankan dengan baik, tetapi juga harus memperhatikan mustahik yang akan diberi bantuan itu benar-benar tidak mampu atau tidak, LAZISMU juga harus terus mengoptimalkan zakat, infaq, shadaqah (ZIS) yang sudah ada dan sudah ditetapkan.

LAZISMU juga berperan aktif dalam mengawasi dan membina mustahik dalam pemanfaatan zakat, infak, shadaqah (ZIS) yang sudah diterimanya agar apa yang sudah diterimanya bisa bermanfaat dan tidak salah dipergunakan, sehingga jika terjadi permasalahan langsung bisa diatasi. Selain itu, pengawasan juga berfungsi sebagai pengukur apakah usaha yang dijalankan oleh mustahik berkembang atau tidak. Dari hasil wawancara yang peneliti lakukan dengan ibu Urip Sumiyati pada hari sabtu, 07 februari 2015 diketahui bahwa zakat sebagai sarana dalam pengentasan kemiskinan dan pemberdayaan perekonomian kecil yang dilakukan oleh LAZISMU. Dana yang diberikan oleh LAZISMU dijadikan usaha oleh ibu Urip Sumiyati dengan berjualan kripik sukun, ibu Urip mulai berjualan sukun dari tahun yang lalu tepatnya pada tahun 2013. Sebelum mendapat bantuan dari LAZISMU keadaan keluarga ekonominya susah karena penghasilannya dan penghasilan suami tidak cukup untuk memenuhi kebutuhan sehari-hari tetapi setelah mendapat bantuan dari LAZISMU keadaan ekonomi keluarga bu Urip Sumiyati mengalami perubahan yaitu bisa untuk bayar sekolah anak dan memenuhi kebutuhan sehari-hari.

Wawancara yang kedua yaitu dengan bapak Miftahurrohman ia adalah seorang pedagang yaitu pada hari kamis, 26 Februari 2015 dan mulai melakukan usaha sekitar tahun 2009. Sebelumnya bapak Miftahurrohman adalah seorang karyawan saja tetapi kemudian keluar dari pekerjaannya 
dan memulai mencoba membuka usaha baru kecil-kecilan yaitu kios pertanian dan samapi sekarang bapak Miftahurrohman masih menjalani usaha tersebut. Pelayanan yang dilakukan oleh LAZISMU sangat baik dan sangat membantunya sejak tahu bahwa ada dana tanpa bunga untuk modal usaha. Setelah mendapat bantuan dana dari LAZSIMU pendapatan keluarga dari bapak Miftahurrohman bertambah dan sangat cukup untuk menambah perekonomian keluarga dan untuk membiayai sekolah kedua anak bapak Miftahurrohman. Masukan untuk LAZISMU adalah harus menumbuhkan dan meningkatkan lagi pengusaha-pegusaha baru agar masyarakat yang dulunya menjadi seorang mustahik bisa menjadi seorang muzaki nantinya dan dapat menjadikan orang yang dulu pengangguran bisa menjadi seorang pengusaha karena berdasarkan data statistik lebih dari 20\% tingkat kemiskinan di daerah Banyumas masih sangat tinggi.

Wawancara yang ketiga yaitu dengan bapak Imam Subandi yaitu pada hari kamis, 26 Februari 2015 dan mulai melakukan usaha pada tahun 2009, sebelum mendapat bantuan dari LAZISMU, bapak Imam Subandi adalah seorang distributor krupuk. Kemudian mendapat bantuan dari LAZISMU untuk berwirausaha sendiri. Menurut bapak Ima Subandi Untuk pelayanan yang dilakukan oleh LAZISMU sangat baik dan sangat bisa membantunya dalam melakukan usaha. Semua dana yang diterima oleh bapak Imam Subandi ia gunakan untuk modal usaha, setelah mendapat bantuan dana dari LAZISMU, bapak Imam Subandi sangat bisa membantu keadaan ekonomi keluargany dan peran LAZISMU untuk usaha bapak Imam Subandi Sangat penting untuk menjalankan usaha.

Penuturan dari para mustahik ini dapat dijadikan bukti bahwa zakat benar-benar mampu dalam pemberdayaan perekonomian mustahik di Banyumas dan itu dapat direalisasikan oleh LAZISMU Banyumas dengan menerapkan berbagai strategi baru yang pas dan benar-benar dibutuhkan oleh masyarakat dengan memberikan bantuan modal usaha kepada para mustahik dan akan terus dipantau perkembangannya oleh badan pelaksana yang turun secara langsung bertemu dengan para muzaki dan para mustahik jadi tidak hanya sekedar komsumtif saja. Faktor penunjang dan faktor penghambat strategi LAZISMU dalam pemberdayaan mustahik Banyumas adalah 
1. Faktor penunjang

Adapun faktor penunjang yang dilakukan oleh LAZISMU Banyumas adalah lembaga yang mempunyai sumber daya manusia yang baik dan manajemen pengelolaan yang kreatif untuk mengelola dana yang diberikan oleh para muzakki untuk mustahik, fasilitas yang memadai juga penting untuk keperluan dan kebutuhan para pengurus LAZISMU juga menggunakan sistem toleransi dan persaudaraan sehingga perbedaan itu memacu untuk terus bekerja sama untuk kesetaraan masyarakat dan semua pihak yang terlibat dalam kepengurusan LAZISMU ini sebagai salah satu penunjang baik secara struktural, kelembagaan dan peran kesadaran umat untuk lebih paham dengan perintah zakat, infaq, shadaqah (ZIS) yaitu dengan terus mengadakan program-program baru yang dapat menarik minat para muzakki untuk menyisihkan sebagian dari harta mereka untuk para mustahik, LAZISMU akan terus mengoptimalkan dalam mengatasi pemberdayaan perekonomian masyarakat.

Dengan adanya program-program yang sudah dijalankan oleh LAZISMU seperti pemberdayaan ekonomi masyarakat ( pemberdayaan ekonomi kecil, kewirausahaan pemuda, kampung kreatif,) pemberdayaan pertanian dan peternakan (prtanian dan perkebunan, community development, permodalan, peternakan dan perikanan) pengembangan pendidikan (beasiswa berprestasi, beasiswa khusus, bakti guru), gerakan sedekah seribu rupiah (GESSER), rumah kreatif muhammadiyah, indonesia siaga. Ini menjadi salah satu faktor penunjang yang dilakukan oleh LAZISMU dalam pemberdayaan perekonomian mustahik yang ada di Banyumas, ini sudah dapat dijadikan bukti bahwa peran LAZISMU dalam pemberdayaan perekonomian sudah sangat baik dan benar.

2. Faktor penghambat

Adapun faktor penghambat LAZISMU adalah masih banyaknya dari para pengurus muhammadiyah yang belum memiliki kesadaran 
untuk membayar zakat, infaq, shadaqah (ZIS) mereka untuk para mustahik ini menjadi salah satu penghambat dalam pemberdayaan perekonomian masyarakat, minimnya respon dari para AUM untuk dapat bersinergi dengan LAZISMU untuk bekerjasama untuk terus mengoptimalkan program-program yang sudah diagendakan.

LAZISMU sangat penting bagi memberdayaan perekonomian masyarakat, lambatnya respon dari PCM dan PRM yang memiliki lembaga zakat, infaq, shadaqah (ZIS) untuk mendirikan jaringan LAZISMU, sehingga pendirian jejaring di cabang dan ranting yang ditargetkan belum dilakukan secara maksimal ini juga menjadi kendala, minimnya kapasitas sumber daya manusia dilapangan baik kulaitas dan kuantitas, minimnya sumber daya manusia yang berkualitas, karena pekerjaan untuk menjadi seorang pengelola zakat, infaq, shadaqah (ZIS) tidaklah mudah dan belum menjadi tujuan hidup atau profesi seseorang bahkan dari lulusan ekonomi syariahpun, pemahaman tentang fiqh amil belum memadai, masih minimya pemahaman seorang amil zakat, infaq, shadaqah (ZIS) yang belum tahu benar tentang bagaimana mengelola zakat dengan baik karena mereka hanya memandang zakat, infaq, shadaqah (ZIS) hanya dapat diberikan secara komsumtif saja, masih rendahnya kesadaran masyarakat untuk membayar zakat, infaq, shadaqah (ZIS) ini menjadikan salah satu kendala yang dialami oleh LAZISMU dalam mengatasi perekonomian. Sistem informasi zakat juga menjadi salah satu faktor penghambat untuk mengatasi perekonomian mustahik. Salah satu program yang belum bisa dijalankan oleh lembaga amil zakat infaq shadaqah Muhammadiyah (LAZISMU) yaitu belum terlaksananya program tentang toko kmunitas ini menjadi salah satu penghambat yang ada di LAZISMU, tetapi meskipun ini belum terlaksana akan terus mencoba membuat toko komunitas terlebih dahulu dan akan bekerja sama dengan majelis ekonomi agar toko komunitas dapat terlaksanakan ditahun ini

\section{PENUTUP}

Zakat sangat berperan dalam mengatasi peberdayaan perekonomian mustahik hal ini terbukti dengan bekembangnya usaha para mustahik 
yang semakin meningkat. Penilaian masyarakat/mustahik terhadap keberadaan lembaga amil zakat infaq shadaqah Muhammadiyah (LAZISMU) Banyumas yaitu benar-benar sangat membantu untuk melakukan usaha karena dari LAZISMU akan terus membantu masyarakat Banyumas agar bangkit dari keterpurukan dan kemiskinan untuk menuju masyarakat yang makmur. Namun keterbatasan modal yang dialami oleh para mustahik juga perlu diperhatikan oleh LAZISMU. Perkembangan usaha yang dilakukan oleh mustahik dapat menjadi tolak ukur seberapa besar strategi yang dilakukan LAZISMU dalam mengatasi pemberdayaan perekoomian mustahik. Adanya faktor penunjang yaitu LAZISMU yakni mempunyai sumber daya manusia yang baik dan manajemen pengelolaan yang kreatif untuk mengelola dana yang diberikan oleh para muzaki untuk mustahik, fasilitas yang memadai juga penting untuk keperluan dan kebutuhan para pengurus. Adanya faktor penghambat yaitu masih banyaknya dari para pengurus muhammadiyah yang belum memiliki kesadaran untuk membayar zakat, infaq, shadaqah (ZIS) mereka untuk para mustahik, minimnya respon dari para AUM untuk dapat bersinergi dengan LAZISMU untuk bekerjasama untuk terus mengoptimalkan program-program yang sudah diagendakan.

\section{DAFTAR REFERENSI}

Ahmad, Dzajuli. 2002. Lembaga-lembaga Perekonomian Umat. Jakarta : PT Raja Grafindo Persada.

Arif, Nur. Al Rianto . 2012. Lembaga Keuangan Syariah. Bandung : CV Pustaka Setia

Azizy, Qodri. 2004. Membangun Pondasi Ekonomi Umat. Yogyakarta : Pustaka Pelajar

Burhan, Bungin. 2011. Metodologi Penelitian Kuantitatif. Jakarta : Kencana

Departemen Agama Islam RI,1989. Al-Qur'an dan Terjemahnya. Semarang: CV. Thoha Putera

Didin, Hafidhuddin. 2002. Zakat Dalam Perekonomian Modern. Jakarta : Gema Insani

Durri, Andriani, et. al. 2012, Metode Penelitian, Cetakan Keempat. Universitas Terbuka, Tanggerang Selatan

Geasil Rendra Yuspi dkk. 2008. Islamadina Jurnal Pemikiran Islam. Purwokerto : Fakultas Agama Islam 
Kristiono, Dwi. 2006. Studi Analisis terhadap Badan pelaksana Urusan Zakat Muhammadiyah Cabang Waleri Daerah Kendal. Semarang

Lexy, J. Moleong. 2004, Metodologi Penelitian Kualitatif. Bandung: Remaja Rosdakarya

Makhrus, M. "Aktivisme Pemberdayaan Masyarakat dan Institusionalisasi Filantropi Islam di Indonesia." ISLAMADINA(2014): 23-44.

Mufraini, Arief. 2006. Akuntansi Manajemen Zakat. Jakarta: Kencana

Majid, Abdul. 2013. Strategi Pembelajaran. Bandung : PT Remaja Rosdakarya Offset

Noeng, Muhadjir. 2002, Metodologi Penelitian Kualitatif. Yogyakarta: Bayu Indra Grafi.

Ridwan, Muhammad. 2005. Manajemen Baitul Maal Wa Tamwil (BMT), Yogyakarta : UII Press

Shalehuddin, Wawan. Sofyan. 20011, Risalah zakat, Infaq dan Shadaqah. : Tafakur

Sugiyono. 2010, cet. ke-IV, Memahami Penelitian Kualitatif, Bandung : CV. Alfabeta

Suyitno, dkk. 2005. Anatomi Figh Zakat, Yogyakarta : Pustaka Pelajar

Undang-Undang RI No. 23 tahun 2011 tentang pengelolaan zakat

Qardawi, Yusuf 1986. Hukum Zakat, Jakarta : PT Pustaka Litera Nusantara

Zuhayly, Al. Wahbah. 2008. Zakat Kajian berbagai Mazhab. Bandung : PT RemajaRosdakarya

Afiyati, Erlina. 2011. Skripsi. Manajemen Pengelolaan Zakat Produktif di Unit Pengumpul Zakat (UPZ) Kantor Kementrian Agama Kabupaten Wonogiri. Yogyakarta : UIN Sunan Kalijaga.

Anshori, fahrudin. 2010. Skripsi. Analisis Penyaluran Dana Zakat pada LAZIS Sabilillah Malang. Malang : UIN Maulana Malik Ibrahim.

Kristiono, Dwi. 2006. Skripsi. Studi Analisis terhadap Badan pelaksana Urusan Zakat Muhammadiyah Cabang Waleri Daerah Kendal. Semarang : IAIN Walisongo 